\title{
PENGARUH PENERAPAN MODEL RECIPROCAL TEACHING TERINTEGRASI MIND MAPPING TERHADAP PEMAHAMAN KONSEP SISWA PADA MATERI FILUM ARTHROPODA
}

\author{
The Effect of Application Reciprocal Teaching \\ Integrated Mind Mapping Model towards Student's Comprehension Concept on \\ Phyllum Arthropoda
}

\author{
Nurmasari Sartono, Ratna Komala, Helda Dumayanti \\ Pendidikan Biologi Fakultas MIPA Universitas Negeri Jakarta Email: \\ nurmasari_sartono@yahoo.com
}

\begin{abstract}
The Arthropoda Phyllum is part of the Biology subject that requires an understanding of concepts. One of models for these subject is a reciprocal teaching integrated mind mapping model. This model make the students better to understand and easier to remember it for the relationship between various concepts, and their visualization and image colours. The purpose of this research was to know the effect of reciprocal teaching integrated mind mapping model application towards to student's understanding concept on Arthropoda Phyllum. The research was conducted in SMA 105 Jakarta from February until March 2016. The research method was used a quasi-experimental with research design posttest-only control group design. Sample handling technical was used simple random sampling method. The instrument of these method was comperehension concept posttest in the form of multiple choice objective test accompanied by CRI index (Certainty of Response Index) or the scale of confidence of respondents in answering questions. Based on data analysis result, showed that data as normally distributed and homogeny. The conclusions of this research show there is effect of application reciprocal teaching integrated mind mapping model toward student's comperehension concept on Phyllum Arthropoda.
\end{abstract}

\section{Keywords : Arthropoda, concept, mind mapping, reciprocal teaching}

\section{PENDAHULUAN}

Pembelajaran adalah proses untuk membantu siswa agar dapat belajar dengan baik (Suardi, 2015). Pencapaian tujuan pembelajaran dipengaruhi oleh proses pendidikan yang memiliki peran penting dalam mencapai pemahaman konsep. Pemahaman konsep dapat ditingkatkan melalui model pembelajaran reciprocal teaching. Model reciprocal teaching merupakan model pembelajaran konstruktivisme yang dapat meningkatkan antusias siswa dalam memahami materi pelajaran. Reciprocal teaching terdiri dari empat strategi yang diperlukan siswa dalam diskusi kelompok yaitu questioning (membuat pertanyaan), summarizing (merangkum bacaan), clarifying (mengklarifikasi), dan predicting (memprediksi) (Keenan \& Evans, 2009).

Salah satu strategi dalam model reciprocal teaching adalah memahami materi pelajaran dengan cara merangkum. Merangkum dapat dilakukan secara kreatif, efektif dan inovatif dengan menggunakan mind mapping. Pembelajaran dengan mind mapping dapat meningkatkan ingatan dengan cara mengasosiasikan dan mengimajinasikan konsep, serta kata kunci yang saling berhubungan membuat siswa semakin mudah 
memahami materi (Devi et al., 2015). Selain mind mapping, cara merangkum dapat menggunakan media flip chart. Media flip chart adalah lembaran kertas yang berisikan bahan pelajaran yang tersusun rapi dan baik (Kustandi \& Sutjipto, 2009).

Pembelajaran pada materi Biologi membutuhkan pemahaman konsep yang baik. Pada pelajaran Biologi terdapat banyak konsep-konsep, salah satunya adalah materi Filum Arthropoda. Secara umum, beberapa kendala yang dialami siswa pada materi Filum Arthropoda yaitu pembelajaran yang didominasi oleh kegiatan menghapal, banyak istilah latin dan cara membedakan beberapa kelas pada Filum Arthropoda (Zubaidah et al., 2012). Berdasarkan survei dari beberapa sekolah di SMA Jakarta, siswa cenderung belajar materi Biologi dengan cara menghapal sehingga siswa kurang dalam memahami konsep-konsep pada pembelajaran Biologi.

Berdasarkan hasil penelitian Laili (2014), model reciprocal teaching terintegrasi mind mapping merupakan salah satu model yang dapat meningkatkan pemahaman siswa dan keterampilan bertanya sehingga dapat meningkatkan hasil belajar kognitif siswa pada konsep Sistem Sirkulasi. Selain itu, hasil penelitian mengenai model pembelajaran reciprocal teaching terintegrasi mind mapping dapat meningkatkan pemahaman konsep IPA pada siswa (Mahayanti et al., 2012).

Model pembelajaran yang tepat untuk mengatasi kendala yang dialami siswa dalam memahami konsep menjadi hal yang penting untuk mencapai tujuan pembelajaran. Penerapan model reciprocal teaching terintegrasi mind mapping dalam pembelajaran materi Filum Arthropoda diharapkan dapat mengatasi kendala yang dialami siswa dalam pemahaman konsep. Berdasarkan uraian tersebut, maka perlu dilakukan penelitian tentang "Pengaruh Penerapan Model Reciprocal Teaching Terintegrasi Mind Mapping terhadap Pemahaman Konsep Siswa pada Materi Filum Arthropoda".

\section{METODE PENELITIAN}

Penelitian dilaksanakan di SMAN 105 Jakarta pada bulan Februari-Maret 2016 pada kelas X Semester Genap dengan metode kuasi eksperimen. Variabel bebas dalam penelitian ini adalah model reciprocal teaching terintegrasi mind mapping, sedangkan variabel terikat adalah pemahaman konsep siswa pada materi Filum Arthropoda. Sampel penelitian yang didapatkan dari populasi terjangkau yaitu kelas X MIA B (kelas kontrol) sebanyak 30 siswa dan X MIA C (kelas eksperimen) sebanyak 30 siswa yang diambil dengan teknik simple random sampling.

Instrumen yang digunakan pada penelitian adalah tes pemahaman konsep (posttest) materi Filum Arthropoda dalam bentuk pilihan ganda yang disertai dengan indeks CRI (Certainty of Response Index). Indeks CRI (Certainty of Response Index) adalah skala keyakinan responden (siswa) dalam menjawab pertanyaan (Potgieter et al., 2005). Instrumen yang telah disusun diuji coba terlebih dahulu untuk mengetahui validitas dan reliabilitas instrumen. Hasil uji validitas menggunakan rumus point biserial diperoleh 38 soal valid. Hasil uji reliabilitas menggunakan rumus KR-20 diperoleh bahwa instrumen memiliki nilai reliabilitas sangat tinggi, yaitu sebesar 0,89. Data hasil tes pemahaman konsep yang diperoleh, dianalisis setelah dilakukan uji prasyarat analisis dan uji hipotesis statistik. Pengujian prasyarat analisis berupa uji normalitas menggunakan uji Kolmogorov-Smirnov dan uji homogenitas menggunakan uji F pada taraf signifikansi $5 \%$ atau $\alpha=0,05$. Uji hipotesis statistik menggunakan uji $\mathrm{t}$, dilakukan apabila data yang diuji homogen dan berdistribusi normal pada taraf signifikansi $5 \%$ atau $\alpha=0,05$. 


\section{HASIL DAN PEMBAHASAN}

\section{Hasil}

1. Hasil Tes Pemahaman Konsep Siswa pada Kelas Eksperimen

Berdasarkan hasil data penelitian diperoleh rentang hasil tes pemahaman konsep siswa pada kelas eksperimen menggunakan model reciprocal teaching terintegrasi mind mapping lebih banyak terletak pada rentang nilai interval 81-86 yaitu sebanyak 10 siswa. Rentang hasil tes pemahaman konsep siswa pada kelas eksperimen dapat dilihat pada Gambar 1 sebagai berikut :

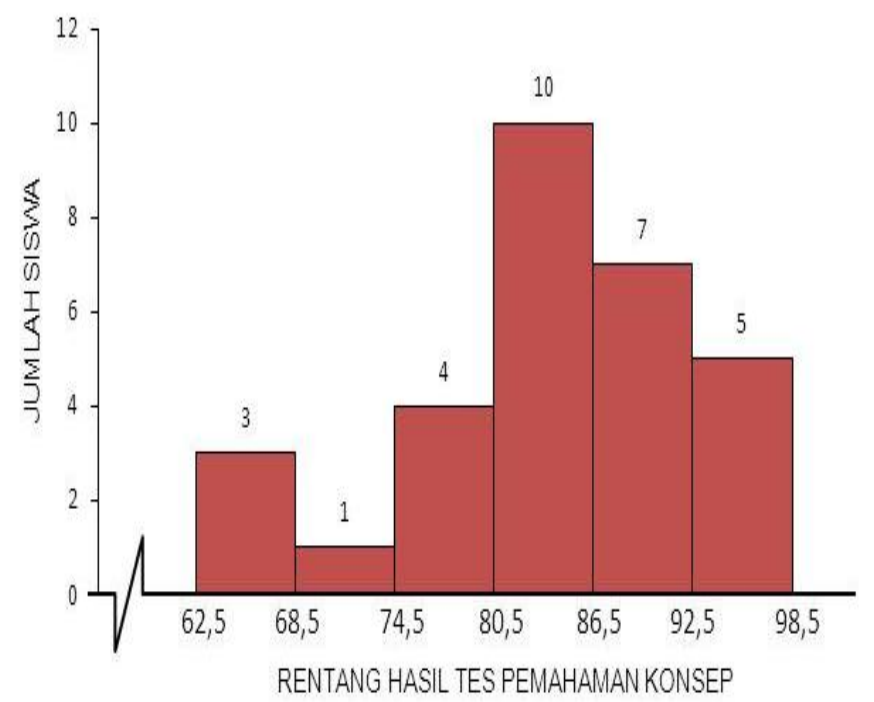

Gambar 1. Rentang Hasil Tes Pemahaman Konsep Siswa pada Kelas Eksperimen

\section{Hasil Tes Pemahaman Konsep Siswa pada Kelas Kontrol}

Berdasarkan hasil data penelitian diperoleh rentang hasil tes pemahaman konsep siswa pada kelas kontrol menggunakan model reciprocal teaching terintegrasi flip chart lebih banyak berada pada rentang nilai interval 73-79 yaitu sebanyak 9 siswa. Rentang hasil tes pemahaman konsep siswa pada kelas kontrol dapat dilihat pada Gambar 2 sebagai berikut :

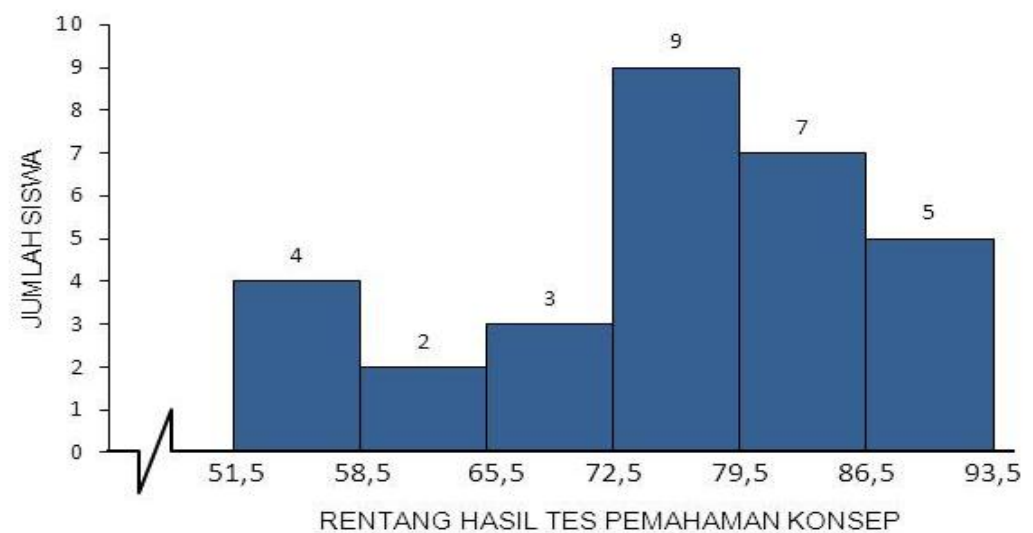

Gambar 2. Rentang Hasil Tes Pemahaman Konsep Siswa pada Kelas Kontrol

3. Perbandingan Rata-Rata Hasil Tes Pemahaman Konsep Siswa pada Kelas 


\section{Eksperimen dan Kelas Kontrol}

Rata-rata hasil tes pemahaman konsep siswa pada kelas eksperimen yaitu 84,2 lebih tinggi dari pada kelas kontrol yaitu 75,8. Rata-rata hasil tes pemahaman konsep siswa pada kelas eksperimen daN kelas kontrol dapat dilihat pada Gambar 3 sebagai berikut :

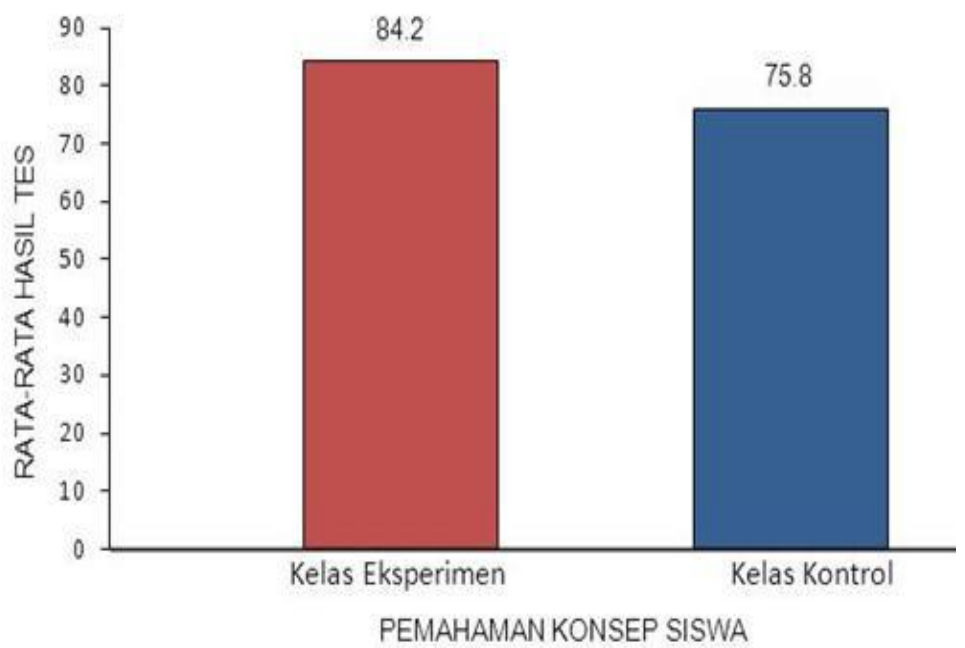

Gambar 3. Rata-Rata Hasil Tes Pemahaman Konsep Siswa pada Kelas Eksperimen dan Kelas Kontrol

\section{Perbandingan Persentase Siswa yang Paham Konsep pada Kelas Eksperimen dan} Kelas Kontrol

Berdasarkan hasil penilaian rata-rata persentase skor CRI siswa dalam menjawab soal posttest dari ketiga indikator pembelajaran, diketahui siswa yang paham konsep tertinggi pada kelas eksperimen terdapat pada indikator 1, yaitu 81,3\% dan kelas kontrol juga terdapat pada indikator 1 , yaitu $71,8 \%$ yang dapat dilihat pada Gambar 4 sebagai berikut :

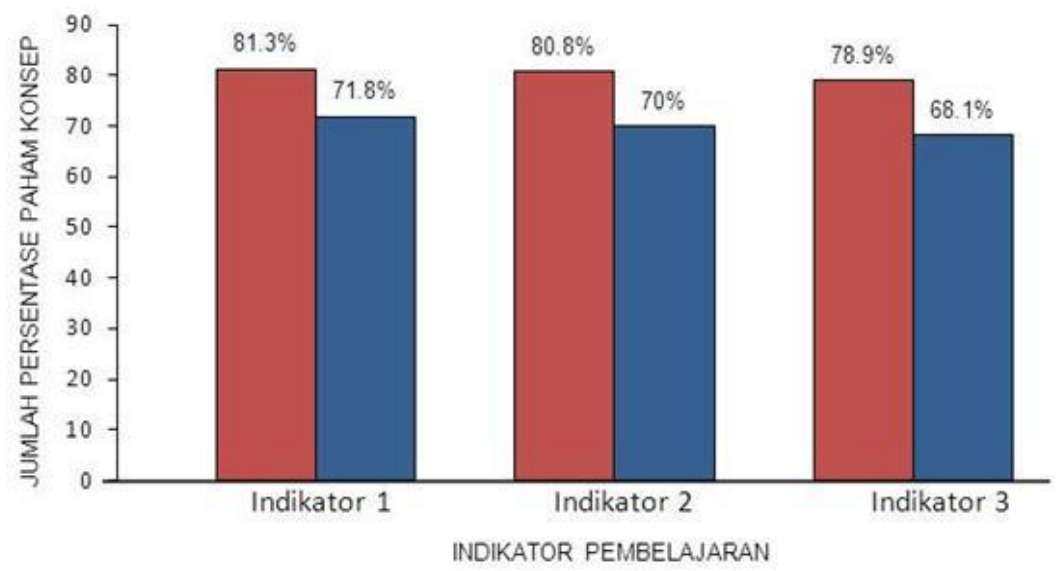

Gambar 4. Persentase Siswa yang Paham Konsep.

5. Perbandingan Persentase Hasil Keterlaksanaan Pembelajaran Pada Kelas Eksperimen dan Kontrol

Rata-rata persentase hasil dari observasi keterlaksanaan proses pembelajaran pada kelas eksperimen sebesar 95\% dan pada kelas kontrol sebesar 93,34\% tergolong dalam kriteria sangat baik (Riduwan, 2012) yang dapat dilihat pada Gambar 5 sebagai berikut : 


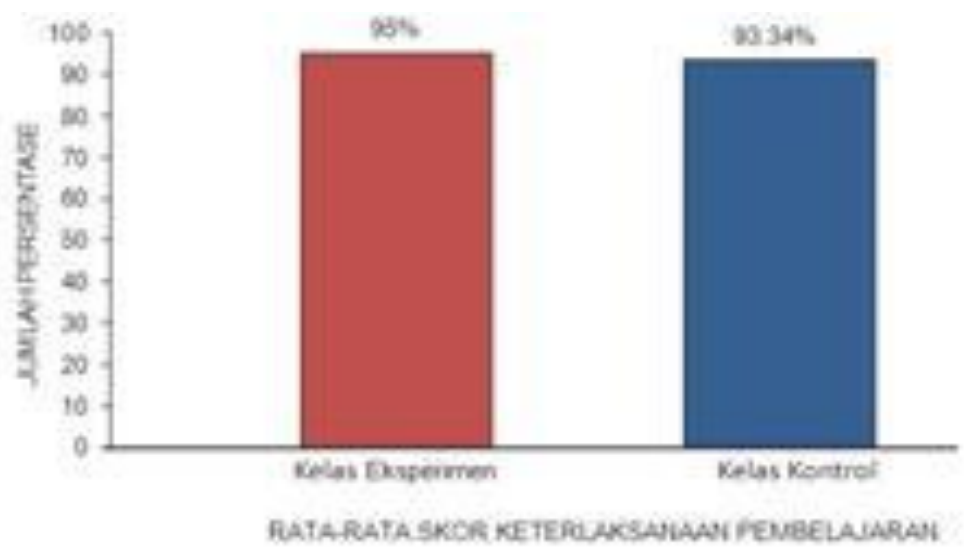

Gambar 5. Persentase Hasil Keterlaksanaan Pembelajaran

\section{Pembahasan}

Berdasarkan data hasil tes pemahaman konsep siswa pada kelas eksperimen dan kelas kontrol menunjukkan bahwa penerapan model reciprocal teaching terintegrasi mind mapping berpengaruh terhadap pemahaman konsep siswa pada materi Filum Arthropoda. Pada kelas eksperimen diperoleh hasil rata-rata pemahaman konsep siswa lebih tinggi yaitu 84,2 daripada kelas kontrol yaitu 75,8. Hal ini menunjukkan bahwa penerapan model reciprocal teaching terintegrasi mind mapping memiliki pengaruh lebih baik terhadap pemahaman konsep siswa pada materi Filum Arthropoda.

Pada Filum Arthropoda terdapat banyak konsep-konsep yang membutuhkan pemahaman belajar yang baik. Beberapa kendala yang dialami siswa yaitu cara membedakan kelas pada Filum Arthropoda dan adanya istilah Latin sehingga dibutuhkan pemahaman konsep yang baik.

Berdasarkan hasil posttest, pemahaman konsep dengan model reciprocal teaching terintegrasi mind mapping dapat meningkatkan pemahaman konsep siswa. Model pembelajaran tersebut dapat memfokuskan perhatian siswa pada materi pelajaran karena siswa terlibat aktif dalam proses pembelajaran dan mengkonstruk sendiri konsep yang telah dipelajari sehingga pembelajaran lebih bermakna bagi siswa (Mahayanti et al., 2012).

Adanya pengaruh yang lebih baik pada pemahaman konsep siswa di setiap indikator pembelajaran dapat dilihat dari rata-rata persentase Certainty of Response Index (CRI) yang dimiliki siswa dalam menjawab soal. CRI (Certainty of Response Index) didasarkan pada suatu skala yang diberikan bersamaan dengan soal yang diujikan untuk mengetahui pemahaman konsep yang dimiliki oleh siswa (Potgieter et al., 2005).

Kendala-kendala belajar siswa dalam memahami materi Filum Arthropoda mengenai ciri-ciri umum Filum Arthropoda dan perbedaan kelas dari klasifikasi Filum Arthropoda berdasarkan ciri-ciri serta struktur tubuh. Kendala-kendala belajar siswa dapat teratasi dengan baik melalui penerapan model reciprocal teaching terintegrasi mind mapping. Penerapan model reciprocal teaching terintegrasi mind mapping, memungkinkan siswa secara mandiri untuk menjelaskan pemahaman konsep mengenai materi Filum Arthropoda dengan membuat mind mapping sebagai bentuk rangkuman yang kreatif dan menarik. Mind mapping merupakan teknik memvisualisasikan hubungan antar berbagai konsep dengan adanya warna dan gambar (Liu et al., 2014).

Pada pembelajaran reciprocal teaching di kelas, guru akan memberikan contoh bagaimana menggunakan strategi pada model reciprocal teaching dalam memahami 
bacaan, kemudian siswa mempelajari langkah-langkah tersebut dan menerapkannya (Bender, 2012). Reciprocal teaching terdiri dari empat strategi yaitu questioning (membuat pertanyaan), summarizing (merangkum bacaan), clarifying (mengklarifikasi), dan predicting (memprediksi) (Keenan \& Evans, 2009).

Pada pembelajaran model reciprocal teaching, siswa melakukan diskusi mengenai materi Filum Arthropoda dan secara bergantian siswa menyampaikan hasil pemahaman bacaan berdasarkan ciri-ciri umum serta perbedaan klasifikasi dari Filum Arthropoda. Hasil diskusi kelompok, kemudian dituliskan pada Lembar Kerja Siswa (LKS) yang terdapat kolom-kolom yang digunakan untuk mengisi hasil diskusi dalam memahami materi dari Filum Arthropoda. Reciprocal

teaching melibatkan tiap siswa dalam kelompok untuk menggunakan strategi memahami bacaan dalam diskusi kelompok (Keenan \& Evans, 2009).

Model reciprocal teaching mengajarkan strategi memahami bacaan dan meningkatkan kemampuan belajar dari teks yang sulit. Model reciprocal teaching digunakan untuk membantu siswa memusatkan perhatian pada apa yang sedang dibaca dan membuat siswa memahami bacaannya (Efendi, 2013). Berdasarkan hasil diskusi memahami bacaan, siswa merancang rangkuman dalam bentuk mind mapping pada kelas eksperimen dan flip chart pada kelas kontrol. Prinsip model reciprocal teaching adalah perkembangan kognitif yang terjadi melalui internalisasi konsep dengan adanya interaksi sosial (Klingner et al., 2007).

Penerapan model reciprocal teaching terintegrasi mind mapping menghasilkan pemahaman konsep yang lebih baik. Mind mapping dapat menghasilkan catatan yang memberikan banyak informasi dalam satu halaman dan memperlihatkan hubungan antar berbagai konsep yang mudah diingat. Pembuatan mind mapping membantu siswa dalam meningkatkan pemahaman bacaannya dengan mengeksplorasi kemampuannya dalam merangkum ciri-ciri umum dari Filum Arthropoda, menafsirkan bagian-bagian dari struktur tubuh masing-masing kelas Arthropoda secara mandiri dari gambar yang dibuat dan adanya variasi warna serta garis melengkung yang menghubungkan antar cabang membuat siswa antusias dalam mengerjakan mind mapping.

Mind mapping dapat meningkatkan kerja otak mengoptimalkan kemampuan siswa, menyimpan informasi materi pelajaran ke dalam Long Term Memory (LTM), menstimulasi memori dan kreativitas sehingga mempermudah dalam mengakses informasi yang tersimpan dalam memori. Siswa yang membuat mind mapping dapat memberikan makna pada mind mapping yang dibuat, karena gambar, warna, penggunaan kata kunci sebagai konsep dan keterkaitan antar cabang pada mind mapping dapat menjadi pemicu bagi siswa untuk mengingat kembali suatu konsep pada materi pelajaran (Alga, 2008).

Pada kelas kontrol kegiatan pembelajaran dilakukan dengan cara menerapkan model reciprocal teaching terintegrasi flip chart. Siswa diberi kebebasan dalam membuat rangkuman yang menarik dalam bentuk flip chart. Merangkum menggunakan flip chart berupa uraian singkat, namun hal tersebut membuat siswa kurang dalam memahami materi yang dibaca karena pada rangkuman tidak terdapat keterkaitan kata kunci (konsep) yang memudahkan siswa dalam memahami materi. Keterampilan memahami materi pelajaran dari bacaan merupakan hal yang penting karena dengan membaca seseorang dapat belajar materi pelajaran dengan lebih bermakna (Graesser, 2007).

Tercapainya pemahaman konsep yang baik pada kelas eksperimen dan kelas kontrol juga dipengaruhi oleh keterlaksanaan pembelajaran di kelas. Berdasarkan hasil 
observasi penelitian, rata-rata persentase keterlaksanaan pembelajaran pada kelas eksperimen $(95 \%)$ dan kelas kontrol $(93,34 \%)$ tergolong dalam kriteria sangat baik (Riduwan, 2012). Pada penelitian ini, perlu adanya adaptasi siswa pada pertemuan pertama pembelajaran di kelas dalam melaksanakan strategi memahami bacaan dari model reciprocal teaching dan menuangkan pemahaman bacaannya dengan merancang mind mapping (kelas eksperimen) maupun flip chart (kelas kontrol).

\section{KESIMPULAN}

Berdasarkan analisis data dan pengujian hipotesis yang telah dilakukan, maka dapat disimpulkan bahwa penerapan model reciprocal teaching terintegrasi mind mapping berpengaruh terhadap pemahaman konsep siswa pada materi Filum Arthropoda

\section{DAFTAR PUSTAKA}

Alga, S. (2008). Penerapan Teknik Mind Mapping Bagi Siswa Sekolah Dasar (SD) Dalam Mempelajari Bahan Ajaran Ilmu Pengetahuan Sosial (IPS). Tesis Fakultas Psikologi Universitas Indonesia.

Bender, W. N. (2012). Differentiating Instruction for Student with Learning Disabilities. Publisher: Corwin.

Devi, R.S., Yuliariatiningsih, M.S., \& Mulyati. (2015). Efektivitas Metode Mind Mapping terhadap Peningkatan Pemahaman Konsep Siswa Pada Mata Pelajaran IPA. Jurnal, 3(2): 1-8

Efendi, N. (2013). Pendekatan Pengajaran Reciprocal Teaching Berpotensi Meningkatkan Ketuntasan Hasil Belajar Biologi Siswa SMA. Jurnal Pedagogia, 2(1): 84-97.

Graesser, A.C. (2007). An Introduction to Strategic Reading Comprehension. In D.S. Mcnamara, (2007). Reading comprehension strategies: Theories, interventions, and technologies. (pp.3-23). New York: Lawrence Erlbaum Associates.

Keenan, T., \& Evans, S. (2009). An Introduction to Child Development (second edition). Sage Publications Ltd.

Klingner, J. K., Vaughan, S., \& Boardman, A. (2007). Teaching Reading Comprehension to Students with Learning Difficulties. New York: The Guilford Press.

Kustandi, C., \& Sutjipto, B. (2009). Media Pembelajaran Manual dan Digital. Bogor: Ghalia Indonesia.

Laili, A. M. (2014). Pengaruh Model Pembelajaran Resiprocal Teaching Terintegrasi Mind Mapping Terhadap Hasil Belajar Siswa pada Konsep Sistem Sirkulasi. Skripsi. Universitas Islam Negeri Syarif Hidayatullah Jakarta.

Liu, Y., Zhao, G., Ma, G., \& Bo, Y. (2014). The Effect of Mind Mapping on Teaching and Learning: A Meta Analysis. Standard Journal of Education and Essay, 2(1): 017031

Mahayanti, A., Pudjawan, \& Margunayasa. (2012). Pengaruh Model Pembelajaran Reciprocal Teaching Berbantuan Mind Mapping Terhadap Pemahaman Konsep IPA Siswa Kelas IV Semester II SD No. 1 Baktiseraga. Jurnal Universitas Pendidikan Ganesha.

Potgieter, M., Rogan, M.J., \& Howie, S. (2005). Chemical Concept Inventory of Grades 12 Learners and UP Foundation Year Students. Africans Journal of Research in SMT Education 9(2): 121-134. 
Riduwan. (2012). Belajar Mudah Penelitian untuk Guru-Karyawan dan Peneliti Pemula. Bandung: Alfabeta.

Suardi, M. (2015). Belajar dan Pembelajaran. Yogyakarta: Deepublish.

Zubaidah, N., Santosa, K., \& Utami, N. R. (2012). Pembelajaran Materi Arthropoda dengan Menggunakan Model Investigasi Kelompok pada Kelas X. Unnes Journal of Biology Education. 1(1):64-69. 